\title{
Distribution of Lead and total Hydrocarbon in Tissues of Periwinkles (Tympanotonus fuscatus and Pachymelania aurita) in the upper Bonny River, Nigeria
}

\author{
${ }^{1}$ *IDERIAH,T J K; ${ }^{1}$ BRAIDE, S A; ${ }^{2}$ BRIGGS, A O \\ *1 Institute of Pollution Studies, University of Science and Technology, Port Harcourt \\ ${ }^{2}$ Chemistry Department, University of Science and Technology, Port Harcourt
}

\begin{abstract}
The concentrations of lead and total hydrocarbons in the tissues of the periwinkles Tympanotonus fuscatus and Pachymelania aurita from the upper Bonny River were determined. The highest mean values of lead and total hydrocarbons were $9.45 \mu \mathrm{g} / \mathrm{g}$ and $1242.19 \mu \mathrm{g} / \mathrm{g}$ respectively. The results showed higher concentrations of lead and hydrocarbons in the creeks than in the open river. The concentrations of lead and total hydrocarbons measured at the control site were lower than the concentrations measured at the study sites. The concentrations of $\mathrm{Pb}$ and THC were generally higher in the shells than in the tissues of periwinkles in the study areas. T - tests showed no significant difference in concentration between tissues and shells of the organism with high correlations $(\mathrm{P}<0.05, \mathrm{r}=$ 0.9947 for $\mathrm{Pb}$ and $\mathrm{P}>0.05, \mathrm{r}=0.9611$ for THC). The relationships between the concentrations of $\mathrm{Pb}$ and $\mathrm{THC}$ in the tissues and shells were observed to follow linear and polynomial regression equations. The levels of $\mathrm{Pb}$ and THC were higher along the main river than the creeks as a result of dilution and flushing effects of current and volume of water. The levels of lead and total hydrocarbons in the periwinkles were attributed to emissions from automobiles using leaded gasoline for both land and sea transportation in addition to effluents, oil spills and surface coatings from moving and abandoned engine boats as well as industrial and domestic wastes containing metal parts and hydrocarbons. @JASEM
\end{abstract}

Heavy metal contamination may arise from a number of sources such as urban and industrial wastes, geologic weathering, agricultural sources, natural agrochemical leaching, atmospheric emissions etc (Forstner and Wittman, 1983). Industrial, municipal and other types of wastes discharged into the marine environment contain sufficient quantities of heavy metals to contaminate bays and estuaries. Crude oil and refined products released into lakes, ponds, streams and oceans undergo weathering processes such as spreading and drifting, evaporation, dissolution, dispersion, oxidation, emulsification, adsorption, sinking and sedimentation and shoreline interactions. Heavy metals are known to be insidious toxic pollutants and their presence in the environment, especially aquatic environment is of great concern. There is increasing awareness of the impact of lead exposure on past civilizations as a result of rapid growth in population, expansion of industrial activities, exploration and exploitation of natural resources, modern agricultural practices and lack of environmental regulations (Biney et. al., 1994; Chindah and Sibeudu, 2003). The relatively high exposure of our present civilization and the potential for subtle toxic effects at very low concentrations has caused concerned scientists to urge their governments to control the release of lead into the environment (Nriagu, 1985). Lead is a non essential pervasive element with no known biological requirement. Industrial lead aerosols, lead-soldered cans and lead plumbing are the principal sources of lead contamination in food. Their relative contribution as well as those of other sources, *Corresponding author: *E-mail: tujokid@yahoo.com depends on the food type and the history of exposure during production, harvesting, transport, packaging, preparation and consumption. Oil spills could cause serious damage to marine life and vast destruction of the environment. Contamination of rivers and other inland waters that serve as drinking water source is one of the most serious aspects of oil pollution. Organisms in these environments such as oysters, clams, mussels, periwinkles etc that routinely filter large amounts of water to extract food, may be contaminated. Oil contamination may do little harm to the organism concerned or to its predator, but the presence of oil components may render the flesh unpalatable due to the presence of oily taint. The growth of marine organisms depends basically in the quantity and quality of the primary production of phyto-plankton (algae). Apart from the toxic effects of oil, marine micro-fauna can experience indirect food effects since algal production can be affected after oil spill. Fish, crustaceans and mollusks exposed to oil concentrations may acquire an objectionable oily odour or flavour, thus loosing their market value and inedible in extreme cases. Since 1976, over 2.8 million barrels of crude oil have been released into the environment in 550 reported cases of crude oil spillage in the Niger Delta (Odiete, 1999). After the Funiwa - 5 oil well blow out in January 1980, fish were reported dead and mangrove trees in the impacted area were destroyed (Nwankwo and Irechukwu, 1981). Similarly large expanse of lands and water bodies were affected after the Kwale wells 15 and 16 oil spill in October 2003. 
Mortalities of inter-tidal and sub-littoral animals and plants due to toxic oil components can be caused by spills of refined products or fresh crude oil near shore. Long term sub-lethal effects that impair the ability of marine organisms to reproduce, grow, feed or carry out other physiological or biochemical functions have been demonstrated experimentally (Doerffer, 1992). Periwinkle (Tympanotonus fuscatus and Pachymelania aurita) is a common name for a group of molluscan shellfish with either smooth or rough spiral shells. They are found in the inter tidal zones at low water mark in several parts of the world. Periwinkles crawl about under water but usually remain passive when left uncovered by the tide. They feed on microscopic algae, detritus matter and diatoms. Considerable amounts of periwinkles are obtained daily for food. Periwinkles have been found to be rich in protein and carbohydrates. Egonmwan (1980) estimated the crude protein content of Tympanotonus to be $21.04 \%$. The muscle tissue also contains high concentrations of free arginine, aspartic acid and glutamic acid (Watt and Merril 1950, Jay 1978). Tympanotonus and Pachymelania are commercially valuable periwinkles and their collection and marketing form an important industry in the Niger Delta. Their value compares favourably with those of domestic livestock and fish (Dambo, 1993). It is therefore important to determine the levels of metals in these organisms (Okoye, 1991; Paez-Osuna and Ruizx, 1995). Port Harcourt and its environs and indeed Rivers State have a number of industrial activities including transportation, manufacturing, agricultural and municipal which discharge wastes including refinery and other chemical discharges, spent oil, domestic wastes etc into the inland creeks and rivers. The main objective of this study is to investigate the tissue distribution of lead and hydrocarbons in periwinkles in parts of the Niger Delta area.

\section{MATERIALS AND METHODS}

Description of study stations: The six locations lie within latitudes $4^{\circ} 27^{\prime} 16^{\prime \prime}$ and $4^{\circ} 54^{\prime} \mathrm{N}$ and longitudes $6^{\circ} 56^{\prime} 04^{\prime \prime}$ and $7^{\circ} 35^{\prime} 27^{\prime \prime} \mathrm{E}$ with a mean annual rainfall of over $2000 \mathrm{~mm}$ and mean annual temperature of about $29^{\circ} \mathrm{C}$ (NMS, 1998). Stations 1 - 5 are located at industrial activity areas such as (1) kidney island creek, a slot operated by Shell petroleum development company for transportation, building and maintenance of boats (2) opposite Nigeria Ports Plc where transportation, vessel cleaning and ship building take place, (3) Marine base where transportation, boat/bardge building and abandonment take place, (4) Woji creek where effluent from Trans Amadi industrial area are discharged, (5) Ekerekana creek where effluents from Refineries, Fertilizer company and other industries are discharged and transportation also take place. Station 6, eagle island swamp, located at a nonindustrial area of Port Harcourt serves as a control site.

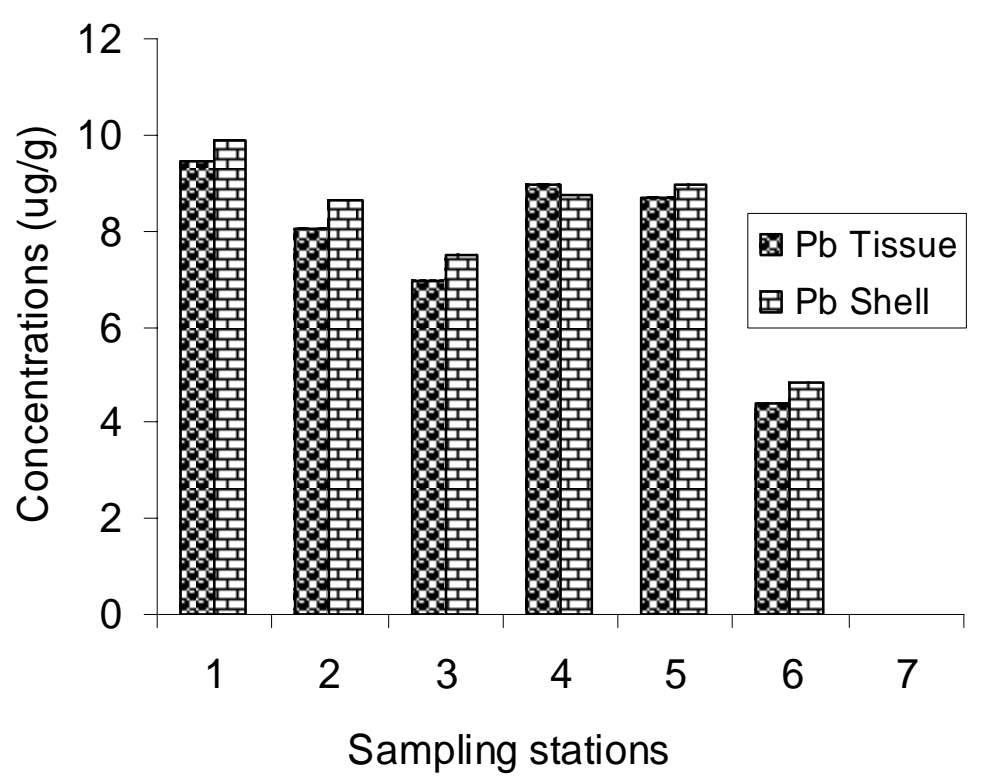

Fig. 1:Concentrations of $\mathrm{Pb}$ in shells and tissues at the study areas

Sample collection, preparation and analysis:_Grids were marked at each station Periwinkle samples were hand picked at ebb tide fortnightly from the study sites at specific locations. Periwinkles were put into 
perforated plastic cans with cover, which had been washed with distilled water and left to dry prior to sample collection, and taken to the laboratory. The samples were washed with distilled water and frozen at $-5^{\circ} \mathrm{C}$ unit they were ready for treatment and analysis. The frozen state facilitated easy de-shelling in addition to preservation of the tissue samples. The soft body tissue was separated from the shell. The portions for lead determination were dried at $60^{\circ} \mathrm{C}$ in an oven overnight and ground to fine powder. The portions for total hydrocarbon determination were air dried at room temperature.

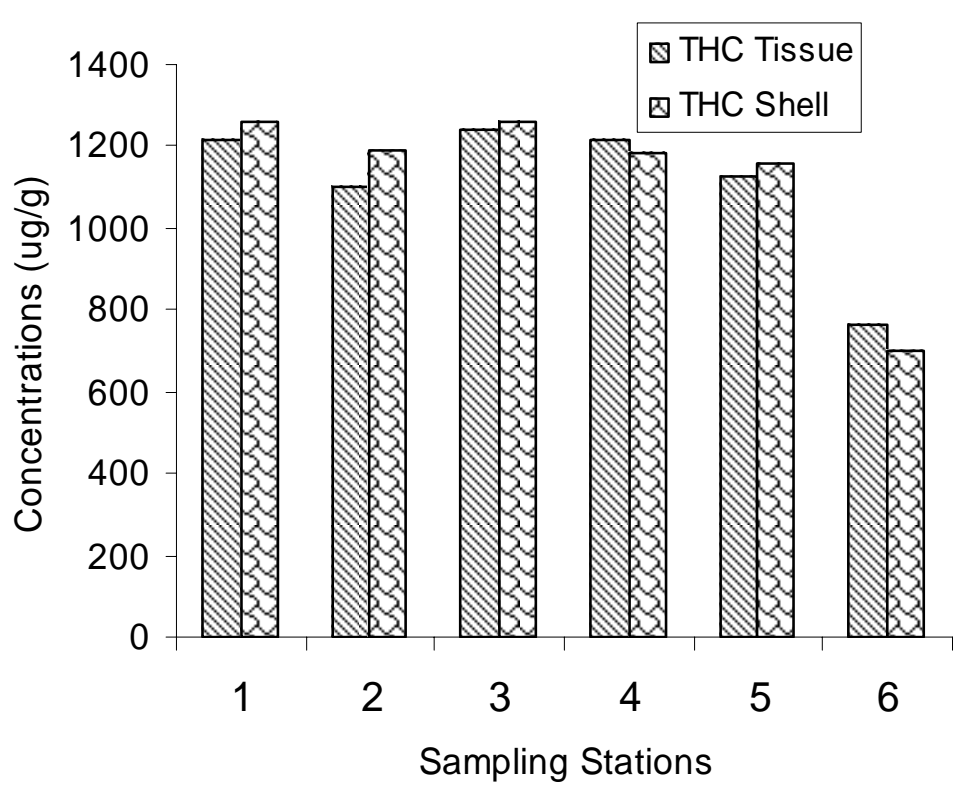

Fig. 2: Relationship between concentrations $(\mathrm{ug} / \mathrm{g})$ of $\mathrm{Pb}$ in tissues and shells

$0.3 \mathrm{~g}$ of each sample was put in a digestion flask and digested with a mixture of $6 \mathrm{ml}$ concentrated nitric acid and $2 \mathrm{ml}$ of $70 \%$ perchloric acid. The mixture was gently and slowly swirled at moderate heat on a hot plate till the solution was clear. It was then set aside to cool. The digest was filtered into a $50 \mathrm{ml}$ volumetric flask, made up to mark with distilled water and concentrations of lead measured in a Varian Atomic Absorption Spectrophotometer model IL. 451 at $217 \mathrm{~nm}$. $5 \mathrm{~g}$ of each air-dried and ground periwinkle samples were shaken for three minutes with $10 \mathrm{ml}$ of toluene to extract the hydrocarbon. The extract was measured spectrophotometrically at 420nm (Chindah and Sibeudu, 2003). 


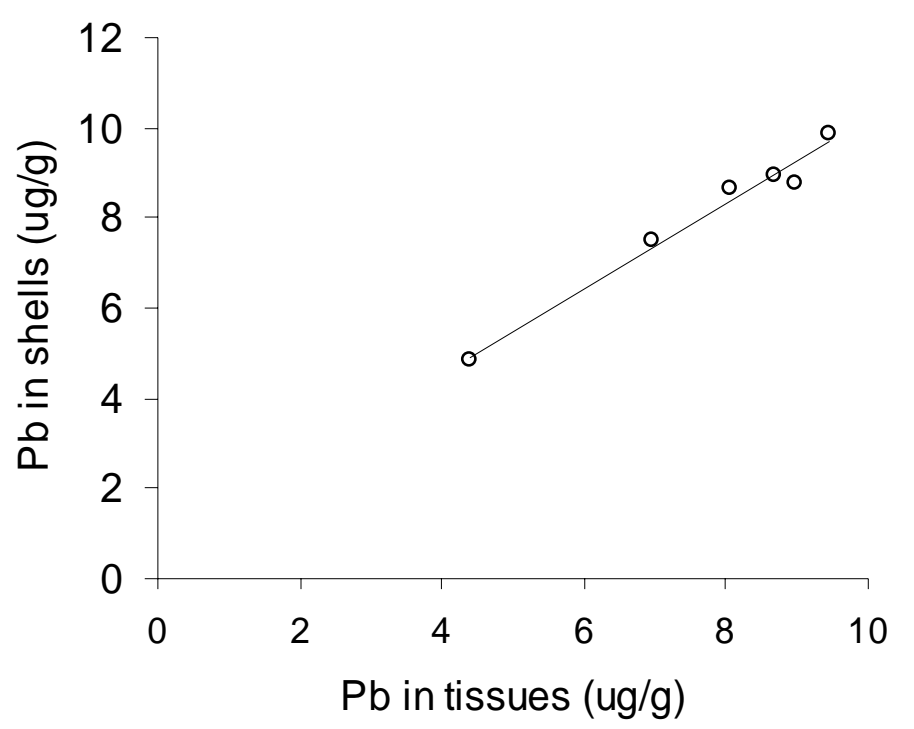

Fig. 3: Relationship between concentrations $(\mathrm{ug} / \mathrm{g})$ of $\mathrm{Pb}$ in tissues and shells

\section{RESULTS AND DISCUSSION}

The results of the concentrations of lead (Pb) and total hydrocarbon (THC) in the tissues of the two species of periwinkle measured in the study areas are presented in table 1.

Table 1:Mean Concentrations ( $\mu \mathrm{g} / \mathrm{g})$ of Lead and Total Hydrocarbons in Periwinkle Tissues.

\begin{tabular}{llc}
\hline \multicolumn{2}{c}{ Station } & \multicolumn{2}{c}{ Concentrations } \\
\cline { 2 - 3 } 1 & No. & \multicolumn{2}{c}{$\mathrm{Pb}$} & THC \\
2 & $9.45 \pm 3.60$ & $1214.63 \pm 46.70$ \\
3 & $8.06 \pm 2.72$ & $1098.75 \pm 30.56$ \\
4 & $6.95 \pm 1.85$ & $1242.19 \pm 208.52$ \\
5 & $8.96 \pm 1.78$ & $1216.74 \pm 86.13$ \\
6 & $8.68 \pm 3.24$ & $1124.00 \pm 102.47$ \\
\hline
\end{tabular}

The mean lead concentration in periwinkle tissues varied from $4.39 \mu \mathrm{g} / \mathrm{g}$ to $9.45 \mu \mathrm{g} / \mathrm{g}$ and the mean total hydrocarbon concentrations in the periwinkle tissues varied from $764.31 \mu \mathrm{g} / \mathrm{g}$ to $1242.19 \mu \mathrm{g} / \mathrm{g}$. The results show variations within stations and samples with no particular trend. This is attributed to variations in the level of activity at each station and the extent of discharge into the water body. The lower mean level of THC at station 2 could be attributed to reduced transport activity around the station. The lower mean level of $\mathrm{Pb}$ at station 3 could be attributed to the location and distance of the station from the road. This implies that emissions from automobile activities on the major roads close to the stations contributed to the level of pollution. Marine transport using leaded gasoline is prominent in the area. Thus the level of pollution observed could also be attributed to discharges, spills, surface coatings and metal parts from boats and other vessels. Wave actions and tidal changes influence the levels of pollution in the periwinkles by either depositing or washing away these discharges on the shores and swamp. The concentrations of both $\mathrm{Pb}$ and THC were higher at stations $(1-5)$ where there are more industrial activities than the control station (6), which is mainly residential. The levels measured at the control suggest that in addition to tidal actions, discharges of metal and THC containing domestic wastes also contributed to the level of pollution in the periwinkles. Although the levels of $\mathrm{Pb}$ varied between stations ANOVA shows that their differences are not significant except at the control station. Except at the control, station 6, the mean level of THC is higher in the creeks (stations $1,3-5$ ) 
than in the open river (station 2). However, Pb levels did not show similar trend. The high concentrations of THC in the tissues could also be attributed to anthropogenic and biogenic THC in the tissues. The lower values in the main river could be attributed to the higher energy of current and volume of the water, which dilute and ensure proper flushing as well as increased urbanization and industrialization around the creeks.

The concentrations of $\mathrm{Pb}$ and THC were generally higher in shells than in tissues in the study areas except at station 4 for $\mathrm{Pb}$ and stations 4 and 6 for THC (Figs. 1 and 2). The differences between them were not significant with high correlations $(\mathrm{P}<0.05$; $r=0.9947$ for $\mathrm{Pb}$ and $\mathrm{P}>0.05 ; \mathrm{r}=0.9611$ for $\mathrm{THC}$ ). Fig. 3 and 4 respectively show the relationships between the values of $\mathrm{Pb}$ and THC in the shells and tissues and their respective regression equations and correlation coefficients. It shows that the values of $\mathrm{Pb}$ in shells and tissues best fitted a linear regression equation (1) while those of THC best fitted a polynomial regression equation (2).

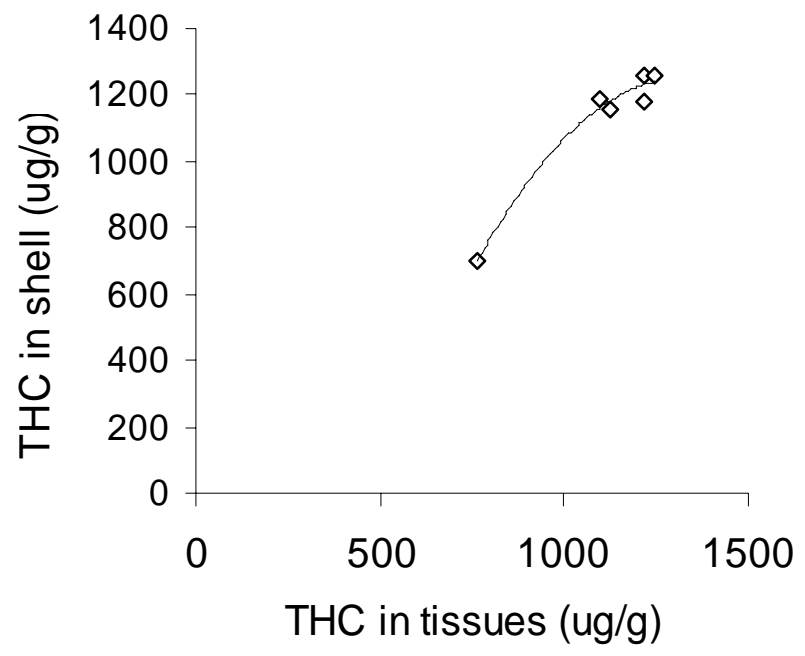

Fig. 4: Relationship between concentrations (ug/g) of THC in tissues and shells

Conclusion: This study has provided information on the levels of lead and THC pollution in periwinkle tissues and shells in the study areas for future assessment of environmental contamination and aquatic pollution. The results have shown that there are obvious contamination problems in the creeks. In addition to leaded gasoline, domestic and industrial wastes containing metals and hydrocarbons discharged into the river contributed to the levels of pollution in the periwinkles. Also the study has shown that periwinkles have lead concentrations that may elicit sublethal toxicity. In general the levels of $\mathrm{Pb}$ and THC are harmful to humans through the eating of contaminated periwinkles, which are

$$
\begin{aligned}
& y=b x+c \\
& y=a x^{2}+b x+c(2)
\end{aligned}
$$

Where: $y=$ mean concentration of contaminants in the shells; $\mathrm{a}$ and $\mathrm{b}=$ coefficients corresponding to intercept on $\mathrm{y}$ axis; $\mathrm{c}=$ slope; $\mathrm{x}=$ concentration of contaminants in the tissues

The trend lines show the projected trends with the actual data from this study. The values and trends of contaminants observed in this study indicate that both tissues and shells are good accumulators of pollutants in effluents and other wastes generated and discharged into the river system. The results of this study are generally higher than those of earlier studies in the main Bonny river channel (Eweozor and Snowden, 1987; Kakulu et al., 1987; Claude and Azokwu 1999). The results generally show that lead concentrations were lower than limits $(10 \mathrm{mg} / \mathrm{kg})$ previously reported in shell fish (Egan et al, 1981). However the values obtained in this study are similar to those reported in previous studies that suggested sublethal toxicity in humans (NAS, 1980, Boeckx, 1986, USEPA, 1986, Sharp et al, 1987).

important sources of protein and minerals in the Niger Delta area of Nigeria. The use of leaded gasoline should therefore be discouraged and oil spills should be avoided or properly cleaned while effluents should be treated before discharged into water bodies.

\section{REFERENCES}

Biney C A; Amuzu, A T; Calamari, D; Kaba, N; Nbome, I L; Naeve, H; Ochumba, P B O; Osibanjo, O; Radegonde V; Saad M A H (1994): Review of Heavy metals p $30-60$. In Calamari D and $\mathrm{H}$ Naeve (eds) Review of 
pollution in African Aquatic Environment FOA/CIFA Technical paper 25.

Boeckx, R L (1986): Lead poisoning in children: Anal chem..; 58, 274A-287A.

Chindah, A C; Sibeudu, O E (2003): Levels of hydrocarbons and heavy metals in sediment and a Decapod crustacean (Crab-uca tangeri) in the Bonny/New Calabar river estuary, Niger Delta. Ochroma Srodowiska izasobow Naturals ur 25/26, 2003 r.

Claude, R J; Azokwu, M (1999): Heavy metals in bivalve (Anadara Senile senilis) from Nigeria. Mar. Pollut. Bull., 38, (7): 618 - 622.

Dambo, W B (1993): Tolerance of the periwinkles pachymelania aurita and tympanotonus fuscatus to refined oils. Environ Pollut; 79,203-296.

Doerffer, J W (1992): Oil spill response in the marine environment. Pergamon press Headington hill hall, England. P7-73.

Egonmwan, I R (1980): On the biology of tympanotonus fuscatus var radula (gastropoda, prosobranchia, potamidae). M. Sc. Thesis, University of Lagos. 145p.

Ekweozor I K E ; Snowden, R L (1987): The impact of a minor oil spillage in the estuarine Niger Delta. Mar Pollut. Bull, 8 (11) 595 - 599.

Forstner, U.; Wittman, G T W (1983): Metal pollution in the aquatic environment Second revised edition Springer - Verlag Heidelberg. New York.

Jay, J M (1978): Spoilage in fresh and cured meats, poultry and seafoods in modern microbiology. Second edition. D. Van Nostrand Co. New York. P 135 - 140.

Kakulu, S E; Osibanjo O; Ajayi, S O (1987): Trace metal content of fish and shellfishes of the Niger Delta area. Environ. Internat 13,247 - 251.

National Academy of Sciences (NAS) (1980): Committee on lead in the human environment.
Lead in the human environment. Washington D. C.

NMS, (1998): Nigeria Meteorological services report pp. 1 - 10

Nriagu, J O (1985): Historical perspective on the contamination of foods and beverages with lead. In K R Mahaffey ed: Dietary and environmental lead: Human health effects. Elsevier, Amsterdam. The Netherlands. P 1 - 41

Nwankwo, J N; Irrechukwu, D O (1981): Proceedings of international seminar on the petroleum industry and the Nigerian environment. November 9-12, (1981). Petroleum training institute, Warri Delta state, Nigeria.

Odiete W O (1999): Environmental physiology of Animals and pollution, Diversified Resource Ltd. Lagos pp 204-218.

Okoye, B C O (1991): Heavy metals and organism in the Lagos lagoon. Int J Environ. Stud. 37, 285 292.

Paez-Osuna, F; Ruizx, F A (1995): Trace metals in the Mexican shrimps P Vannamel from estuarine environment. Environ. Pollution 87: p 243 - 247.

Sharp, D S; Becker, C E; Smith, A H (1987): Chronic low-level lead exposure: its role in the pathogenesis of hypertension. Med. Toxic; 2, $210-232$

U .S. Environmental protection agency, (1986): Air quality criteria for lead. Vol.4 US EPA, Environmental criteria and assessment office, research Triangle Park, N. C. EPA/600/883/028df.

Watt, B K; Merril, A L (1950): Composition of foods; raw processed, prepared. Agricultural handbook. No 8 U.S. Department of agriculture, Washington D. C. 